\title{
Antibiotikum stewardship
}

\author{
Antimicrobial stewardship
}

\author{
RÁKAY ERZSÉBET DR. \\ Észak-Közép-budai Centrum Új Szent János Kórház és Szakrendelő, Budapest
}

\begin{abstract}
ÖSSZEFOGLALÁS
A nem megfelelö antibiotikum-alkalmazás komoly betegbiztonsági kockázatot jelent. A szükségtelen vagy nem hatásos antibiotikum-kezelés adott esetben jelentös mellékhatásokat okozhat, emellett elösegíti az antibiotikum-rezisztens baktériumok kialakulását, ezáltal veszélyezteti az antibiotikumok általános terápiás hatékonyságát és alkalmazhatóságát. Az ellátás minden szintjén tapasztalható nem megfelelö antibiotikum használat visszaszoritása, az antimikrobiális rezisztencia kialakulásának megakadályozása tehát globális népegészségügyi jelentőségü probléma, melynek megoldására javasolt az antibiotikumok felhasználására vonatkozó intézményi antibiotikum stewardship program kialakitása. Ennek fö alapelve, hogy a betegnek mindig a megfelelö kezelést kell megkapnia, megfelelö időben, megfelelö ideig és megfelelö dózisban. Fontos célkitüzés, hogy ,, az antibiotikum kezelés gondoskodó szabályzása" a betegek meggyógyítása mellett segitsen megörizni az antibiotikumok hatékonyságát, megakadályozni a rezisztens kórokozók elszaporodását, csökkenteni az egészségügyi ellátás költségeit.
\end{abstract}

\section{Kulcsszavak: antibiotikum stewardship - betegbiztonság - rezisztencia - infekciókontroll}

\section{SUMMARY}

Inappropriate use of antibiotics poses a serious risk to patient safety. Unnecessary or ineffective antibiotic treatment can potentially lead to significant side effects and also promote the development of antibiotic-resistant bacteria thereby endangering the overall therapeutic efficacy and applicability of the antibiotics. Inadequate antibiotic use at all levels of medical care and the development of antimicrobial resistance is therefore a global public health problem, to avoid it institutional antibiotic stewardship program is needed. The basic principle of antibiotic stewardship is the right treatment, at the right time, at the right duration and in the right dose. The most important goal is "the careful regulation of antibiotic treatment", that is while healing the patients, preserving the effectiveness of the antibiotics, preventing the spread of resistant pathogens, and reducing the cost of the health care.

\section{Key words: \\ antibiotic stewardship - patient safety - resistance - infection control}

\section{Az antimikrobiális rezisztencia, mint globális népegészségügyi probléma}

A biztonságos betegellátás az egészségügyi ellátó rendszer bármely szintjén felelősséggel dolgozó egészségügyi személyzet törekvése. A beteg az ellátó rendszeren belül kiszolgáltatott. Azért lépi át az egészségügyi intézmény kapuját, mert szeretné, ha egészségügyi problémájára gyógyírt találna. Brook 1996-ban így fogalmazta meg a ,minőség” fogalmát: „Ha Ön vagy én felkeressük az orvosunkat, biztosak akarunk lenni abban, hogy az összes olyan ellátásban részesülünk, amelyre szükségünk van, és hasonlóképpen biztosak akarunk lenni abban, hogy nem részesülünk olyan ellátásban, amelyre nincs szükségünk" $(1,2)$. A minőségi betegellátás, a betegbiztonság egyik legérzékenyebb mutatója az egészségügyi ellátással összefüggő fertőzések előfordulásának aránya az intézményekben. Ezen belül Európában és ezen belül Magyarországon is az antibiotikum rezisztencia jelenti az egyik legnagyobb betegbiztonsági kockázatot. A szükségtelen vagy nem hatásos antibiotikum-kezelés jelentős mellékhatásokat okozhat, emellett elősegíti az antibiotikum-rezisztens kórokozók kialakulását.

Az antibiotikum-felhasználás minőségét mérő, átfogó adatgyüjtésen alapuló indikátorok, valamint hazai felmérések

Levelező szerző: Rákay Erzsébet dr. e-mail: dr.rakay.erzsebet@gmail.com 
egyaránt azt mutatják, hogy bár Magyarországon európai viszonylatban az átlagnál kevesebb antibiotikumot használnak, a felhasználás módja gyakorta ésszerütlen. A felmérésekből az is kiderül, hogy Magyarországon az őszi-téli időszakban jelentősen megnő az antibiotikum felhasználás, ami arra enged következtetni, hogy az erre az időszakra jellemző vírusfertőzésekre is gyakorta kapnak a betegek antibiotikumot (3). Szintén a szükségesnél nagyobb arányban kapnak a betegek antibiotikumot az aszimptomatikus bakteriuriák megszüntetése végett, vagy lokális sebfertőzések, bőrfertőzések terápiájaként is.

A fölösleges antibiotikum használat - a rezisztencia kialakulásán túl - a legújabb kutatások szerint jóval nagyobb károkat okoz az antibiotikumot kapó betegek szervezetében, mint ahogy eddig gondoltuk. Azt, hogy a normál bélflóra, a testünk szerves részét képező mikrobiom összetételének rossz irányú változása milyen káros lehet az egész szervezetünkre nézve, az elmúlt évtizedek Clostridium difficile járványai is bizonyították. De a legújabb kutatási eredmények szerint a bélrendszerünket kolonizáló baktériumok pszichés állapotunkat is nagymértékben befolyásolják (,,bél-agy tengely”), pszichés állapotunk pedig szoros összefüggést mutat az immunrendszerünk müködésével (4).

A kórházi környezetben - de sajnos a területen is - előforduló, súlyos bélgyulladást okozó Clostridium difficile fertőzések utóbbi években történő elöretörése, a fertőzések leküzdésére használt antibiotikum terápia miatt kialakult rezisztencia helyzet, sajnos a rezisztencia kialakulás, a rezisztens törzsek terjedésének iskolai példáját tükrözi. A Cl. difficile fertőzések terápiájában másodikként választható antibiotikum a vancomycin, mely a bélrendszerbe juttatva (per os adagolás) elpusztítja a $\mathrm{Cl}$. difficile aktív vegetatív formáit. De mint az antibiotikumok általában a vancomycin sem szelektíven csak a clostridiumokra hat, hanem a bélflóra összes vancomycinre érzékeny baktériumát elpusztítja. Kivéve azokat, amelyek vancomycinre rezisztensek. Így szelektálódnak szép csöndesen évek óta beleinkben a vancomycin rezisztens Enterococcusok, melyek aztán föleg nosocomiális fertőzések kórokozóként nehezítik meg a kezelöorvosok, és hát elsősorban a gyógyulni vágyó betegek életét.

A globális népegészségügyi jelentőségü problémát jelentő antimikrobiális rezisztencia (AMR) nem csak Magyarországon figyelhető meg, világszerte mindenhol előfordul, prevalanciája egyre nagyobb gondot jelent. A WHO valamint az európai és amerikai járványügyi szervezetek (Európai betegségmegelőzési és Járványvédelmi Központ (ECDC), Centers for Disease Control and Prevention (CDC)) évtizedek óta szorgalmazzák a világ összes kórházában olyan antibiotikum stewardship programok bevezetését, melyeknek célja a rezisztencia megfékezése, a megbetegedések számának csökkentése, a költségek mérséklése a járó és fekvőbeteg ellátásban egyaránt. A, globális cselekvési terv" részeként az Amerikai Egyesült Államok (USA) és az Európai Unió (EU) közötti együttmüködés javítása érdekében 2009-ben létrejött egy úgynevezett Transzatlanti Antimikrobiális Rezisztencia Munkacsoport (Transatlantic Taskforce on Antimicrobial resistance (TATFAR)). Az együttmüködés három kulcsterületet érint:
1. Megfelelő terápiás felhasználás az orvosi és állatorvosi gyakorlatban (lakosság és egészségügyi dolgozók edukációja)

2. Nozokomiális és területi gyógyszer rezisztens fertőzések megelözése

3. Új antibiotikumok kutatása.

A TATFAR eredményeként jelentősen megnőtt az információ csere az EU és az USA között. Az együttműködéshez kapcsolódóan mindhárom kulcsterülethez számos kampány és program került megvalósításra mind az USAban, mind az EU-ban (5).

\section{Antibiotikum stewardship program az intézményekben}

Az antibiotikum rezisztencia terjedésének megakadályozása az intézményi infekciókontroll tevékenység fő célja. Ez a cél csak akkor érhető el, ha az egészségügyi ellátás minden szintjén törekszünk arra, hogy megelőzzük azt, hogy ezek a multirezisztens kórokozók kolonizáció vagy fertőzés formájában megtelepedjenek betegeinkben. Hiszen a rezisztencia terjedésének legnagyobb gyakorlati problémája, hogy az antibiotikum választás lehetősége beszükül, nem tudjuk meggyógyítani a betegeinket. Tehát minél kevesebb fertőzött betegünk van, annál kevesebb annak az esélye, hogy antibiotikum terápiát kell indítanunk. A nosocomiális fertőzések megelözésének alapja pedig nem különbözik az egyéb fertőző betegségek megelőzésének elveitől: azonosítani és lehetőség szerint kiiktatni szükséges a fertőző forrást, és meg kell akadályozni, hogy a fertőző forrásból a kórokozó direkt vagy indirekt módon átjusson másik személybe. Az indirekt mód pedig azt jelenti, hogy folyamatosan tisztában kell lennünk azzal a ténnyel, hogy a beteg környezetében a kórokozó folyamatosan jelen van, a tárgyak, eszközök, de legfőképpen az egészségügyi dolgozók keze, ruházata által pedig áthurcolható, átadható másik betegnek, ha az alapvető fertőtlenítési szabályok sérülnek. Az egészségügyi dolgozók egy része a folyamatos oktatások ellenére nem fél eléggé ezektől a kórokozóktól. Pedig a védőeszköz-használat és a fertőtlenítés szabályainak megszegésével nem csak a többi beteget veszélyeztetjük, hanem adott esetben magunkat, családunkat, azt a környezetet, ahol a privát életünk zajlik. Átgondoljuk e, hogy milyen kórokozókat viszünk haza a telefonunkon, az óránkon, ékszereinken, azokon a ruháinkon, melyeket a betegellátást követően nem a kórházi mosodába küldünk? Hogyan fertőtlenítjük az öltönyt, nyakkendőt, hőérzékeny anyagból készült civil ruháinkat, ha nem tartjuk be a védőruha használatára vonatkozó elöírásokat?

Az elkülönített beteg ápolására vonatkozóan szinte minden intézmény rendelkezik megfelelő protokollokkal, előírásokkal. A folyamatos infekciókontroll oktatások részét képezik ezeknek az elöírásoknak az ismertetése, melyek betartása mindannyiunk felelőssége. Ez az infekciókontroll tevékenység a rezisztencia terjedését megelőző stratégia egyik alappillére.

A rezisztencia terjedésének megakadályozásában a másik alappillér az antibiotikum stewardship. Az antibiotikum 
stewardship a hivatalos megfogalmazás szerint egy adott intézményre vagy az egészségügyi rendszer egészére kiterjedő stratégia, melynek célja az antibiotikumok megfelelő alkalmazásának elősegítése és ellenőrzése (6). A jól müködő antibiotikum stewardship kulcsfontosságú eszköz a gyógyszerfelírási gyakorlat hatékonyságának és eredményességének javításában mind a fekvőbeteg ellátásban, mind az alapellátásban vagy a járóbeteg szakellátásban.

\section{Az antibiotikum stewardship (ABS) programok központi elemei}

I. Vezetöi elkötelezettség: Jó antibiotikum stewardship program müködtetése akár járóbeteg, akár fekvőbeteg ellátó intézményen belül csak akkor lehetséges, ha az intézmény vezetése - felismerve a probléma súlyát - támogatja a program kialakítását és biztosítja a humán, pénzügyi és információtechnológiai forrásokat.

II. ABS team létrehozása: A humán erőforrások tekintetében leszögezhetjük, hogy ez az a program, mely csak akkor tud hatékonyan müködni, ha egy kialakított interdiszciplináris team vezetésével szabályozásra és ellenőrzésre kerül az adott intézmény teljes antibiotikum felhasználása. Fontos egy a program összefogásáért felelős vezető személy kijelölése, aki irányítja a többi kulcsfontosságú szereplő tevékenységét (3).

1. Klinikusok és a betegellátó osztályok orvos- és ápolásszakmai vezetői: a betegeket ellátó orvosok és ápoló személyzet kezében van úgy a megelőzés lehetősége, mint a betegeknél alkalmazott, megfelelő gondossággal és szakértelemmel indított antibiotikum terápia meghatározása. Fontos tehát a közvetlenül a betegellátásban részt vevő egészségügyi személyzet oktatása, meggyőzése, és fontos a visszaellenőrzés, az elért eredmények vagy kudarcok visszacsatolása is feléjük, hiszen változást, javulást csak megfelelő tudatossággal érhetünk el ezen a területen.

2. Fontos lenne, hogy minden intézményben elérhetö legyen az infektológus, aki meghatározza az intézményben alkalmazott terápiás irányelveket a fertőzések terápiájára vonatkozóan, és aki napi szintü konzultációt biztosít a betegágy mellett, amikor a kezelőorvosnak szüksége van rá.

3. Infekciókontroll szakemberek, epidemiológusok: legfőbb szerepük a fertőzések megelőzésére vonatkozó szabályok kialakításában, betartatásában van. Ha nincs fertőzés nem kell antibiotikum. A klinikusok és az infektológus tisztában kell, hogy legyen a multirezisztens kórokozók előfordulásának kockázatával azon az osztályon, ahol empirikus antibiotikum terápiát kell indítani valamelyik betegnél.

4. Mikrobiológiai laboratórium munkatársai: betegszinten a klinikus, az infektológus és a mikrobiológus párbeszéde nyomán a legoptimálisabb antibiotikum terápia meghatározható, a beteg gyógyulásának esélye növelhető. A rendszeresen elkészített és elemzett, a leggyakrabban kitenyésztett kórokozók antibiotikum re- zisztenciájának mértékét tükröző rezisztencia térképek szintén az empirikus antibiotikum választásnál nyújtanak segítséget, és felhívják a figyelmet egy esetleges helyi rezisztencia problémára.

5. Klinikai szakgyógyszerészek: munkájuk egyre nélkülözhetetlenebb egy jól múködő ABS programban. Rendszeresen elemezve a betegellátó osztályok antibiotikum felhasználását, a jó és a rossz trendekre felhívják a figyelmet, lehetőséget teremtve a számok alapján az okok felkutatására, a javító intézkedések meghozatalára.

6. Minőségügyi munkatársak: a betegbiztonság részeként a program során alkalmazott irányelvek, szabályzatok kiadása, koordinálása, oktatása területén szerepük kulcsfontosságú lehet.

III. Gyógyszerrendelési, engedélyeztetési mechanizmusok

1. Irányelvek létrehozás: A gyakran előforduló fertőzésekhez a nemzetközi és hazai útmutatókban foglaltak felhasználásával helyi szabályozásokat kell létrehozni, mely szintén alapfeltétele egy jó antimikrobiális stewardship programnak. A jó szabályozás egy útmutató a kezelöorvos számára, és lehetővé teszi, hogy a program során az antibiotikum felhasználás helyességét ez alapján monitorozzuk, auditáljuk (5).

2. Követés: Az antibiotikum felírási gyakorlat monitoringja és a rendszeres visszajelzés a klinikusok felé szintén hatékony módszer a bizonyítékokon alapuló irányelvek betartásának elősegítésében. A hibák feltárása rendszeres szakmai továbbképzéseken való részvételt indokolhat.

3. Oktatás és szakértelem: A megfelelő antibiotikum használat oktatása egyaránt szükséges a páciensek és a klinikusok körében. Az egészségügyi személyzet oktatása megszilárdíthatja a megfelelő antibiotikum felírási gyakorlatot és javíthatja a betegellátás minőségét (5).

\section{Az antibiotikum felhasználást fejlesztő törekvések}

Az adott intézményre specifikus antibiotikum terápiás protokollok kifejlesztésén és bevezetésén túl az optimális antibiotikum felhasználást támogathatják az alábbi törekvések:

\section{Restrikciós antibiotikum politika:}

Az intézményi antibiotikum felhasználás szabályozására vonatkozó törekvések nem újkeletüek. Az 1980-as évek közepe, vége felé terjedt el az úgynevezett Restrikciós antibiotikum politika, melynek lényege, hogy egyes antibiotikumok adását megtiltják, illetve korlátozzák. Ennek fó célja az, hogy a listán szereplő antibiotikumok hatékonyságát megőrizzék (7). Ezeknek az antibiotikumoknak az adását általában egy szakmai jóváhagyó (infektológus) aláírásához kötik. Ez a módszer akkor tud gördülékenyen és hatékonyan müködni, ha a jóváhagyásra jogosult infektológus a kezelöorvos részére folyamatosan elérhető, jelen van az adott intézményben. Sajnos kevés az infektológus, így ha nem biz- 
tosított az azonnali elérhetőség előfordulhat, hogy a jóváhagyáshoz szükséges aláirás elkerülése érdekében a gyakorló orvos a szakmai szempontokat figyelmen kívül hagyja, inkább a szabadon rendelhető antibiotikumot választja, mely a beteg gyógyulását hátráltatja, rezisztenciát gerjeszt, ezáltal növeli a költségeket (1).

2. Antibiotikum „time out”: az antibiotikum típusának és szükségességének újraértékelése a diagnosztikus eredmények birtokában. Az ebben megfogalmazott ajánlásokat minden járó- és fekvőbeteg ellátásban antibiotikum terápiát indikáló orvosnak szigorúan be kellene tartani:

Minden klinikusnak felül kell vizsgálnia a rendelt antibiotikumot 48 órával a kezelés megkezdését követően az alábbi kérdések megválaszolásával:

- Van-e bakteriális fertőzése a páciensnek?

- Ha igen, a páciens a megfelelő antibiotikumot kapja-e, megfelelő dózisban és megfelelő beadási móddal?

- Alkalmazható e hatékonyabb, szükebb spektrumú, célzott kezelés adott fertőzés esetén?

- Mennyi ideig kell még kapnia a páciensnek az antibiotikumot (5)?

3. Streamlining: A streamlining a 2. vagy 3., majd azt követően a 7. napon történő újraértékelés, és szükség esetén az antimikrobiális terápia beállítása a klinikai adatok és a tenyésztés eredményei alapján. Ekkor az alábbi döntések meghozatalára kerülhet sor:

- leállítás

- átállás egy másik készítményre a tenyésztés eredménye alapján

- átállás orális beadási módra (de-eszkaláció) (5)

\section{4. ,Start smart, then focus!” „Kezdd okosan, majd pon-} tositsd!" (8)

Az angliai kórházakban alkalmazott eszközrendszer, melynek célja az antimikrobiális rezisztencia csökkentése, a betegbiztonság növelése, ezáltal a betegellátás minőségének fejlesztése (5). A program a címében is jelzett „Start smart! ”, „Kezdd okosan!” elv betartása során az alábbi útmutatások betartását követeli meg:

- Ne kezdd el az antimikrobiális terápiát, amíg nem egyértelmüen bizonyított a fertőzés.

- Vegyél fel pontos anamnézist a gyógyszer allergiával kapcsolatban.

- Súlyos szepszis, vagy életveszélyes fertőzések esetén sürgősen, a diagnózistól számított egy órán belül kezdd el a hatékony antibiotikus kezelést.

- Kövesd a helyi antimikrobiális szerek felírására vonatkozó irányelveket.

- Dokumentáld a klinikai indikációt, az alkalmazott gyógyszer nevét, dózisát, és bevitel módját a betegdokumentációban.

- Jelezd a felülvizsgálat és a gyógyszerelés tervezett leállításának időpontját, vagy a gyógyszerelés tervezett időtartamát a betegdokumentációban.

- Kérj mikrobiológiai vizsgálatot a terápia megkezdése elött.
A ,Then focus”, „Majd pontosíts” jelentése:

- A diagnózis pontosítása, az antibiotikum terápia kezdete után 48-72 órával egyértelmü döntéshozatal a terápia további folytatásáról, a lépések szigorú dokumentálása.

- A folytatás öt lehetséges módja:

- Az antibiotikum terápia abbahagyása, ha a fertőzésre nincs bizonyíték.

- Intravénásról orális beadási módra váltás.

- Másik antibiotikum választása - ideális szükebb spektrum választása, ha lehet.

- A megkezdett terápia folytatása, a következő felülvizsgálati időpont kitűzése, vagy a terápia leállításának meghatározása. (5)

\section{Antibiotikum-felhasználás és rezisztencia surveillance, indikátorok alkalmazása:}

Jól müködő intézményi infekciókontroll és antibiotikum bizottságok a vonatkozó jogszabályi előírásoknak megfelelően $(9,10)$ évek óta rendszeresen elemzik az antibiotikum felhasználásra és a leggyakoribb kórokozókra vonatkozó rezisztencia adatokat. Az indikátorok alkalmazása (pl.antibiotikum költség hány százaléka az összes gyógyszerköltségnek, multirezisztens kórokozók incidenciája stb) lehetővé teszi az egyes évek összehasonlítását, valamint más intézmények adataival, vagy országos adatokkal történő összehasonlítást is.

6. Prospektív audit és visszacsatolás: az antibiotikus terápia egy külső szakértő általi felülvizsgálata. A leggyakrabban alkalmazott audit szempontok:

- indikáció megfelelősége, rögzítése az orvosi dokumentációban

- releváns mikrobiológiai vizsgálatok megtörténte

- antibiotikum-választás megfelelőssége, helyi irányelvek követése

- dózis, beadási mód, tervezett időtartam megfelelőssége, dokumentált volta

- mikrobiológiai eredményeken alapuló de-eszkaláció

- intravénásról orális adagolásra áttérés lehetősége, streamlining, kombinációs terápia felülvizsgálata

- terápiás gyógyszer szint monitorozás követelményei

- antibiotikum-használattal összefüggő nemkívánatos mellékhatások követése.

\section{Összefoglalás}

Szakirodalmi összefoglalók sora bizonyítja (11, 12, 13), hogy az intézményi szinten megfelelő szakmaisággal kialakított, a humán és tárgyi feltételek biztosításával létrehozott antibiotikum stewardship programok hosszú távon hozzájárulhatnak ahhoz, hogy a világszerte elterjedt multirezisztens kórokozók terjedését megfékezzük, a kórokozók antibiotikumokkal szembeni rezisztenciájának körét szükítsük, vagy legalábbis megállítsuk. Az is egyértelmüen bizonyított, hogy egyes intézmények ezirányú elszigetelt törekvései becsülendőek, de átfogó nemzeti program hiányában csekély eredményességgel járnak. 
Betegbiztonsági projektek részeként munkacsoportok adaptálják a külföldi jó gyakorlatok útmutatásait, a hazai gyakorlatba való implementáláshoz azonban szükséges lenne $a$ Nemzeti Antibiotikum Stewardship bevezetése, mely egyelöre várat magára. Ennek a programnak mind a járóbeteg-ellátás, mind a fekvőbeteg és a krónikus, hosszú ápolást nyújtó intézetek számára átfogó tervet kellene kidolgoznia a megfontolt antibiotikum felírás és használat érdekében. A program alapelve szerint a hazai antibiotikum-felhasználást a legalacsonyabb indokolt szinten kell tartani, melynek része a kórokozó mielőbbi azonosítására, és az annak megfelelő legszükebb spektrumú antibiotikumnak a megfelelő dózisú és időtartamú alkalmazására való törekvés.

Egyet azonban nem szabad elfelejtenünk. Minden jó program akkor ér valamit, ha a megvalósításában részt vevők megértik annak célját, jelentőségét. Ha kellő ismerettel rendelkeznek ahhoz, hogy egy globális program részeként érezzék a fontosságát annak, amit nekik tenniük kell. Ott a betegágynál. A program sikeressége az abban résztvevők személyén, aktivitásán, tudásán, elkötelezettségén múlik. A humán erőforrás hiánya megakadályozhatja, hogy eredményesen vegyék fel az ABS teamek a harcot a kórokozók, a rezisztencia terjedése ellen. Ha nincs infektológus az intézményben, akkor nincs kitől konzíliumot, tanácsot, segítséget kérni. Az egyetemekről kikerülő ifjú gyógyítók nincsenek felvértezve azzal a tudással, amely a fertőzések ismeretén, a fertőző betegség diagnosztikáján és kezelésén kellene, hogy alapuljon. Valahol itt kellene kezdeni. Oktatni, oktatni, oktatni. Remélhetőleg a jövőben többen leszünk a betegellátó rendszerben, és akkor lesz is kit oktatni.

\section{IRODALOM}

1. Barcs I.: Egészségesen gyógyulni - A centripetális infekciókontroll kézikönyve, Semmelweis kiadó (2019) 490-496.old.
2. Small Business Handbook, OSHA 2209 02R 2005

3. Knausz M., Babarczy B., Szabó A. és mtsai.: Antimikrobás szerek helyes használata. EFOP 1.8.0-VEKOP-17-2017-00001 „Egészségügyi ellátórendszerek szakmai módszertani fejlesztése” projekt, 2018.01.31.

4. Guseo A., Izbéki F, Rajnavölgyi É.: A mikrobiom bél-agy tengely, neuro 2002. Bt., 2017

5. Szabó A., Knausz M., Babarczy B. és mtsai.: Az antimikróbás stewardship-ra vonatkozó bizonyítékokon alapuló nemzetközi irányelvek szisztematikus áttekintése, a hazai adaptálás lehetőségeinek vizsgálata, Állami Egészségügyi Ellátó Központ, 2017. november

6. Hajdú Á,, Szilágyi E., Kurcz A. és mtsai.: Szakpolitikai bizonyíték-összefoglaló: Az antibiotikumok felelös alkalmazásának ösztönzése az antibiotikumrezisztencia visszaszorítására a humán gyógyászatban Magyarországon, [Policy brief. Promoting the appropriate use of antibiotics to contain antibiotic resistance in human medicine in Hungary]. Koppenhaga: Egeszsegugyi Vilagszervezet (WHO) Europai Regionalis Irodaja; 2018 (EVIPNet Szakpolitikai bizonyitek összefoglalok 2. szam.)

7. Szalka A.: Problémaorientált infektológia, Golden Book Kiadó Kft, (2003) 200-203. oldal

8. Start smart- Then Focus. Antimicrobial stewarddship Toolkit for English Hospitals, Public Health England, 2015

9. 20/2009. (VI. 18.) EüM rendelet az egészségügyi ellátással öszszefüggő fertőzések megelőzéséről, e tevékenységek szakmai minimumfeltételeiről és felügyeletéröl.

10. 12/2012. (III. 6.) NEMFI rendelet az egészségügyi ellátással öszszefüggő fertőzések megelőzéséről, e tevékenységek szakmai minimumfeltételeiröl és felügyeletéröl.

11. Manning M. L., Septimus E. J., Ashley E. S. D. és mtsai.: Antimicrobial Stewardship and Infection Prevention - Leveraging the Synergy: A Position Paper Update, Infection Control \&Hospital Epidemiology, april 2018, vol.39, N.4, 467-472.

12. Chambers A., MacFarlane S., Zvonar R. és mtsai.: A recipe for antimicrobial stewardship success:Using intervention mapping to develop a program to reduce antibiotic overuse in long-term care, Infection Controll\&Hospital Epidemiology (2019) 40, 24-31

13. Apisarnthanarak A., Kwa A. L., Chiu C. és mtsai.: Antimicrobial stewardship for acute-care hospitals: An Asian perspective, Infection Controll\&Hospital Epidemiology (2018) 39, 1237-1245.

Érkezett: 2019. 09. 23.

Közlésre elfogadva: 2019. 10. 01.

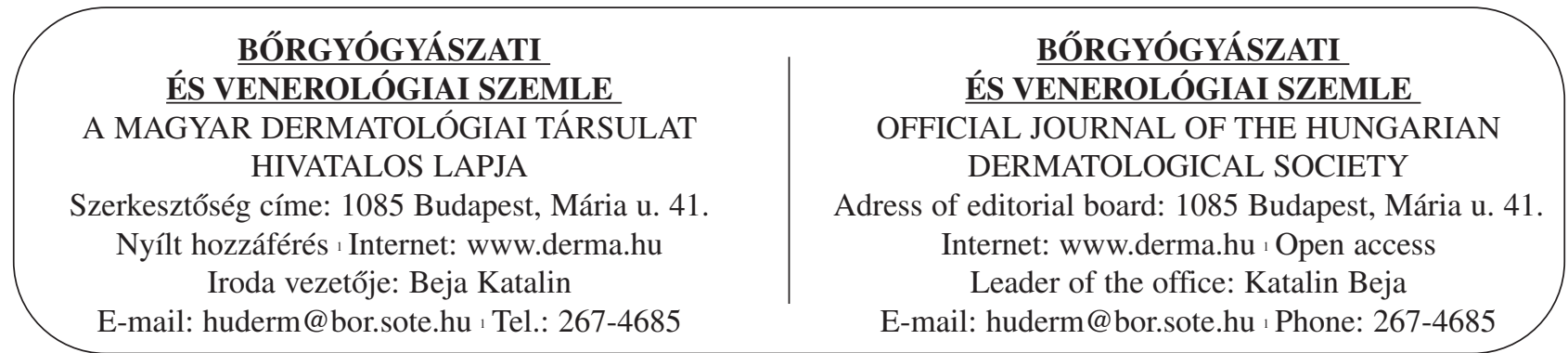

